Revta brasil. Bot., São Paulo, V.23, n.3, p.305-311, set. 2000

\title{
Fly pollination and pollinator sharing in two synchronopatric species: Cordia multispicata (Boraginaceae) and Borreria alata (Rubiaceae)
}

\author{
ISABEL CRISTINA MACHADO ${ }^{1,3}$ and MARIA IRACEMA LOIOLA ${ }^{2}$
}

(received: August 11, 1999; accepted: April 17, 2000)

\begin{abstract}
Fly pollination and pollinator sharing in two synchronopatric species: Cordia multispicata (Boraginaceae) and Borreria alata (Rubiaceae)). The floral biology of Cordia multispicata (Boraginaceae) and Borreria alata (Rubiaceae) was studied in natural populations in a fragment of the Atlantic forest in Pernambuco, northeastern Brazil. Both species flower during almost the whole year. Cordia multispicata is a shrubby species with white, distylous and tubular flowers. Borreria alata is a herbaceous species. Its flowers are whitish, tubular and have a polymorphism in relation to the size of their style. Floral anthesis in both species begins at 6:00 a.m. Sugar concentration in the nectar was about $16 \%$ in C. multispicata and $30 \%$ in B. alata. Nine species of flies, mainly of the genus Palpada (Syrphidae), were observed visiting flowers of the two species. Seven of them were observed visiting and pollinating flowers of both $C$. multispicata and $B$. alata. Two species visited only flowers of $C$. multispicata, whereas no fly was exclusive to $B$. alata flowers. Both species have similar flower morphology, flowering time, habitats in the forest and establish populations very close to each other. These facts can favour the pollinators' sharing and increase pollinator attraction.
\end{abstract}

RESUMO - (Polinização por moscas e partilha de polinizadores em duas espécies sincronopátricas: Cordia multispicata (Boraginaceae) e Borreria alata (Rubiaceae)). Foi estudada a biologia floral e a polinização por moscas em Cordia multispicata (Boraginaceae) e Borreria alata (Rubiaceae) em populações naturais em um remanescente de floresta Atlântica em Pernambuco, Nordeste do Brasil. As duas espécies florescem durante quase todo o ano. Cordia multispicata é uma espécie arbustiva, distílica com flores brancas, pentâmeras e tubulosas. Borreria alata é herbácea, também com flores esbranquiçadas e tubulosas, apresentando um polimorfismo com relação ao tamanho do estilete, em flores da mesma inflorescência. A antese floral em ambas as espécies inicia às $6 \mathrm{~h}$. A concentração de açúcares no néctar é em média de $16 \%$ em C. multispicata e de $30 \%$ em B. alata. Nove espécies de moscas, principalmente do gênero Palpada (Syrphidae), foram observadas visitando flores das duas espécies de plantas, entre as quais sete espécies foram observadas polinizando flores de $C$. multispicata e de B. alata. Duas espécies foram exclusivas a $C$. multispicata e nenhuma visitou exclusivamente flores de B. alata. Ambas as espécies apresentam morfologia floral, "habitat" e período de floração semelhantes, além de estabelecerem populações próximas umas das outras. Estes fatos podem favorecer a partilha de polinizadores e aumentar o potencial de atração das flores dessas plantas.

Key words - Fly-pollination, heterostyly, Atlantic forest, Cordia, Borreria

\section{Introduction}

Many dipterans are flower visitors and show a great variety of modes of pollination, which characterize the syndromes of myophily and sapromyophily (Faegri \& van der Pijl 1979). The family Syrphidae is considered the most important family of Diptera, regarding pollination (Endress 1994, Proctor et al. 1996), but there are still few studies concerning the effective role of these flies as pollinators, especially in tropical regions (Arruda \& Sazima 1996).

1. Departamento de Botânica, CCB, Universidade Federal de Pernambuco, 50372-970 Recife, PE, Brasil.

2. Programa de Pós-Graduação em Botânica, Universidade Federal Rural de Pernambuco, Recife, PE, Brasil. E-mail: loiola@nelore.npde.ufrpe.br

3. Corresponding author: imachado@npd.ufpe.br
The genus Cordia (Boraginaceae) has species adapted to different pollinators. Bees and butterflies are their main visitors, although there are records of pollination by hummingbirds, beetles and flies (Opler et al. 1975). Borreria (Rubiaceae) is apparently an entomophilous genus, however there is almost no information in the literature about the pollination biology of its species.

Cordia multispicata Cham. and Borreria alata DC. have similarities in the size, form and colour of their flowers. In some cases, the similarity of floral characteristics in species of different genera and families may be explained as a convergence towards utilization of the same type of pollinator (Brown \& Kodric-Brown 1979).

In this study we present comparative data about floral biology and pollination by flies in Cordia multispicata and Borreria alata discussing aspects related to floral features, breeding system and polli- 
nator sharing between these two synchronopatric species.

\section{Material and methods}

Field observations were carried out in the Forest Reserve of Dois Irmãos ( $8^{\circ} 7^{\prime} 30^{\prime \prime} \mathrm{S}$ and $\left.34^{\circ} 52^{\prime} 30^{\prime \prime} \mathrm{W}\right)$, in Recife - Pernambuco State, northeastern Brazil. It's one of the few remnants of Atlantic forest in the State. Observations went from August 1992 to July 1993, with additional observations in November and December 1997. The annual rainfall at Dois Irmãos is more than $2000 \mathrm{~mm}$ and mean annual temperature is $25^{\circ} \mathrm{C}\left(20-30{ }^{\circ} \mathrm{C}\right)$. Both species were studied in natural populations distributed at the edges of the forest.

The morphology and size of the flowers, time, sequence and duration of anthesis, colour, emission of odour, sugar concentration in the nectar, as well as time of visits, frequency, and behaviour of the visitors were registered. Measurements of floral parts were based on 10 flowers of B. alata and 20 of C. multispicata (10 short- and 10 long-styled). Sugar concentration in nectar from both species was determined from flowers previously isolated by paper bags on the day prior to anthesis. The sugar concentration was recorded for 20 flowers of $C$. multispicata and 39 of B. alata with a compensated temperature refractometer (Atago). Pollen viability was assessed using acetocarmine (Radford et al. 1974) on 10 flowers of Borreria alata and 20 flowers of Cordia multispicata (10 of each morph), from 10 individuals from each species. In order to examine the reproductive system of C. multispicata, controlled pollinations were performed in the field, according to the methods described by Radford et al. (1974). Treatments included tests for manual self- and cross-pollination. The crosses included flowers of both morphs. Buds were tagged one day before anthesis and the inflorescences were bagged with semi-permeable paper. Treatments were performed at anthesis. To estimate fruit production under natural conditions (control) some, inflorescences were tagged and observed for fruit development. Vouchers of both species are in the herbarium of the Federal University of Pernambuco (UFP 8064 and 8065).

Flowers were observed for visitors between 5:00 a.m. to about 4:00 p.m., during 23 days, totalizing 96 hours of field observations. The behaviour of the visitors was analysed visually and through photographic records. Frequency of the visitors to flowers of both species was registered over three days during the flowering peak, in five plants of each species. Some insects were captured, sent to specialists for identification and stored in the collection of the Laboratory of Floral and Reproductive Biology - Department of Botany, Federal University of Pernambuco.

\section{Results}

Cordia multispicata is a shrub with flowers disposed in dense inflorescences, usually positioned outside the leaves. Inflorescence position varies from erect to hanging, depending on the size of the peduncle, which varies from 2 to $10 \mathrm{~cm}$. The spikes are $2-9 \mathrm{~cm}$ long, with a variable number of flowers
$(\bar{X}=62)$. The inflorescences occur from $10 \mathrm{~cm}$ up to 3-4 $\mathrm{m}$ from the ground. Cordia multispicata is heterostylous, with short- and long-styled flowers, white, pentamerous and tubular (figure 1A). The corolla is about 4-5 $\mathrm{mm}$ long, the stamens are alternipetalous and inserted in the corolla, the pollen is white and powdery and the stigma is four-lobed. The nectary is yellow, annular and is located at the base of the superior ovary. The corolla length in long- and short-styled flowers were not significantly different. The lenght of the filaments is $2.2 \mathrm{~mm}$ in short-styled and $1.6 \mathrm{~mm}$ in long-styled flowers, and the length of the style is 3.0 and $5.0 \mathrm{~mm}$, in shortand long-styled flowers, respectively.

Anthesis begins at 6:00 a.m., and the flowers last until 3:00-4:00 p.m. of the same day. The flowers emit a strong odour, slightly sweet. The sugar concentration in the nectar is $15-16.6 \%(\overline{\mathrm{X}}=16 \%$; $\mathrm{n}=20$ ). The nectar volume is very low (ca. $1 \mu \mathrm{L}$ per flower). Pollen viability is $96 \%$ in both long- and short-styled flowers.

Results of manual pollination experiments (table 1) show that only crosses between different floral types set fruit. Self- and intramorph pollinations were completely incompatible. The fruit set under natural conditions was ca. $48 \%$.

Borreria alata is a herbaceous species, also with tubular flowers (figure 1B) disposed in glomerulous inflorescences. Each glomerule has ca. 65 flowers, and opens 2-4 flowers per day. The flowers are white with a purple corolla tip and are covered with glandular hairs at the tube entrance. The corolla is about $6 \mathrm{~mm}$ long and $4 \mathrm{~mm}$ wide, the stamens are alternipetalous and inserted in the corolla, and the pollen is white and powdery. The nectary is a discon-
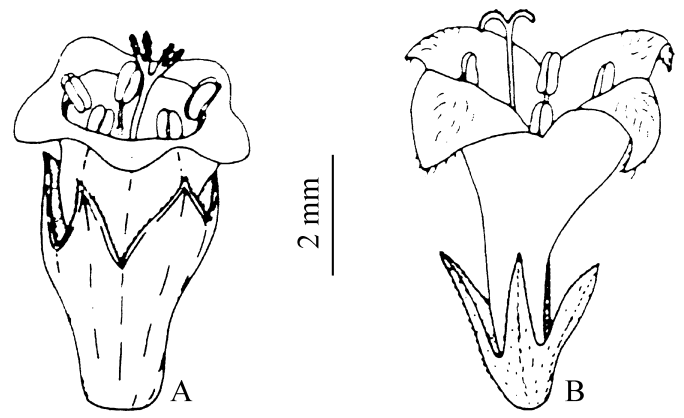

Figure 1. Long-styled flowers of Cordia multispicata (A) and Borreria alata (B). 
Table 1. Controlled pollination and fruit-set under natural conditions (control) in C. multispicata.

\begin{tabular}{lccc}
\hline Treatment & Flowers (number) & Fruits (number) & Success $(\%)$ \\
\hline Self-pollination & 180 & 0 & 0 \\
Cross-pollination & & & 0 \\
$\quad$ Long-styled* X long-styled & 50 & 0 & 0 \\
$\quad$ Short-styled* X short-styled & 60 & 0 & 50 \\
$\quad$ Long-styled* X short-styled & 60 & 30 & 56 \\
$\quad$ Short-styled* X long-styled & 50 & 28 & 56 \\
Control & 240 & 115 & 48 \\
\hline
\end{tabular}

*Pollen donor.

tinuous ring located at the top of the inferior ovary. There is a floral polymorphism in relation to the length of the style and, in some flowers, also in relation to the length of the filaments, which can vary from 0.6 to $1.6 \mathrm{~mm}$. The length of the style varies from 2.5 to $6.0 \mathrm{~mm}$, with some intermediate sizes in the same inflorescence (figure 2).

Anthesis begins at 6:00 a.m. and the flowers last until 2:00 p.m. The flowers are odourless and the mean sugar concentration in the nectar was $30 \%$, varying from 29 to $31 \%(n=39)$. The volume of nectar per flower was ca. 2-3 $\mu \mathrm{L}$. Under natural conditions the fruit set was $78 \%(\mathrm{n}=100)$.

The flowering period of both species extends almost throughout the year, with peaks in the rainy season (from May to July) as well as during the dry season (from October to December).

Nine species of flies, mainly of the genus Palpada (Syrphidae), were recorded on flowers of Cordia multispicata and Borreria alata (table 2). Seven of these fly species were observed pollinating flowers of both $C$. multispicata and B. alata. The same fly can visit flowers of both species, where plants were very close. Two fly species of Dipterans visited exclusively flowers of $C$. multispicata, whereas none visited exclusively flowers of $B$. alata (table 2). The visiting behaviour was similar for all the fly species. During a visit the flies land on the corolla (figure 3), moving towards the nectary and inserting the mouth parts into the central region of the flower, thus drinking nectar. At this time, they touch anthers and stigma with the head, torax, abdomen and/or with the legs. The flies walk on the inflorescences visiting different flowers before moving to another plant. They remain on each flower



Figure 2. Flowers of Borreria alata without the corolla tubes and the stamens, showing the different sizes of the styles in the same inflorescence (x1.6).

from 3 to 50 seconds. The visits occur from 6:00 a.m. to 2:00 p.m., mainly from 8:00 a.m. to $12: 00$ in $C$. multispicata (figure 4).

Two species of Palpada ( $P$. vinetorum and Palpada sp.) were considered as the main visitors and pollinators (figure 4), of both $C$. multispicata and $B$. alata flowers. The former was most frequent in C. multispicata and the latter in B. alata.

Bees (Apis mellifera, Trigona spinipes and Augochloropsis sp.) and butterflies were also observed visiting flowers of the two species. They can pollinate the flowers since they touch the anthers and stigma, but due to their low visiting frequency they were considered as occasional pollinators. 
Table 2. Size and frequency of the Diptera visitors to flowers of Cordia multispicata and Borreria alata.

\begin{tabular}{|c|c|c|c|}
\hline Diptera & Length (mm) & C. multispicata & B. alata \\
\hline \multicolumn{4}{|l|}{ Syrphidae } \\
\hline Ornidia obesa (Fabricius 1775) & 10 & If & Lf \\
\hline Palpada furcata (Wiedemann 1830) & 10 & If & $\mathrm{F}$ \\
\hline Palpada geniculata (Fabricius 1805) & 12 & If & $\mathrm{F}$ \\
\hline Palpada vinetorum (Fabricius 1798) & 12 & vf & Vf \\
\hline Palpada sp.1 & 10 & $\mathrm{f}$ & $\mathrm{F}$ \\
\hline Palpada sp. 2 & 10 & vf & Vf \\
\hline \multicolumn{4}{|l|}{ Calliphoridae } \\
\hline Chrysomya megacephala & 9 & $\mathrm{r}$ & - \\
\hline \multicolumn{4}{|l|}{ Sarcophagidae } \\
\hline Sarcophagula sp & 4 & $\mathrm{r}$ & - \\
\hline \multicolumn{4}{|l|}{ Tachimidae } \\
\hline Not identified & 10 & $\mathrm{r}$ & $\mathrm{R}$ \\
\hline
\end{tabular}

vf- very frequent $>70 \%$ of the total of visits, f- frequent $30-70 \%$, lf- less frequent $10-30 \%$, r-rare $<10 \%$.

\section{Discussion}

Cordia multispicata and Borreria alata have diurnal, whitish, actinomorphic tubular flowers with exposed sexual organs. These attributes together with the easy access to nectar and the high number of flowers per inflorescence attract, in general, a great number of floral visitors, especially those with short mouth parts, as most of the dipterans (Faegri \& van der Pijl 1979, Proctor et al. 1996). Most of the flies of the family Syrphidae have proboscides varing from 2 to $4 \mathrm{~mm}$ (Proctor et al. 1996), which are compatible with the lengths of the floral tubes of the studied species. Although the pollination carried out by small flies can be, in many cases, inefficient due to their size (Proctor et al. 1996), in the case of small flower species, such as C. multispicata and B. alata, these insects seem to be very efficient as pollinators.

The sugar concentration in the nectar varied between the two species, being highest in $B$. alata flowers. According to Vogel (1983), flies and bees prefer a more concentrated nectar than the ones found in B. alata and C. multispicata. On the other hand, Percival (1965) refers to fly-pollinated blossoms with sugar concentration varing from 5 to $15 \%$. Baker (1975) indicates a mean value of $20 \%$ for fly-pollinated flowers, based on the information of Percival (1974). In this same work, Percival found a concentration of $16 \%$ in Borreria laevis, a species visited by many Syrphidae. In turn, Pombal \& Morellato (1995) found a very low sugar concentration (2\%) in the nectar of Dendropanax cuneatum (Araliaceae), a species which is also pollinated by flies. Our data show mean sugar concentrations of $16 \%$ in Cordia multispicata and 30\% in Borreria alata, which reinforce the suggestion of Pombal \& Morellato (1995) that sugar concentrations in the nectar of fly-pollinated flowers may vary widely and does not seem to be a determining factor in the searching for flowers by the flies. The low amount of nectar offered per flower in both species is compensated by the great number of available flowers in each species per day. Flies are known to use variable feeding resources in their diet (Faegri \& van der Pijl 1979), however nectar is on important source of carbohydrates to their metabolism (Vogel 1983).

The visits to the flowers of both species occurred during the morning, mainly between 8:00 a.m. and 12:00, in the case of C. multispicata. In fact, many species of Syrphidae feed only at specific hours of the day (Weems 1953). Regarding specificity, most of them forage on many types of flowers, but they are generally observed on white, greenish, inconspicuous flowers (Faegri \& van der Pijl 1979, Proctor et al. 1996, Weems 1953), such as $C$. multispicata and B. alata flowers.

The flowers of B. alata in contrast to those of $C$. multispicata, emit a strong sweet odour, but this 
attribute as in the case of nectar sugar concentration does not seem to determine the searching for flowers by the flies. Arruda \& Sazima (1996) found that
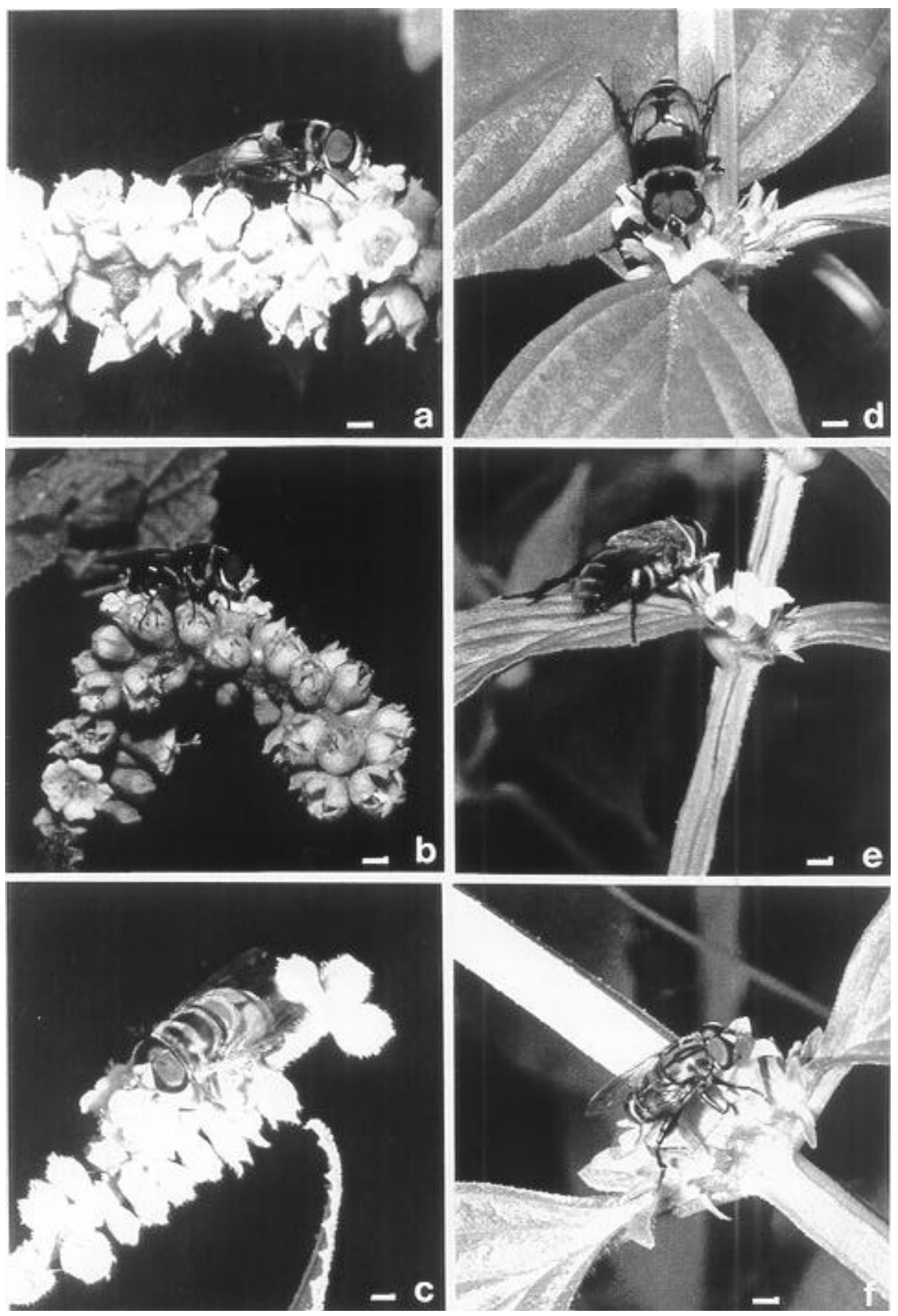

Figure 3. Palpada spp. (Syrphidae) visiting flowers of Cordia multispicata (a- x2.8, b- x2.0, c- x2.6) and Borreria alata (d-f x2.2). a,d-

Palpada sp.; b, e- Palpada geniculata; c- Palpada vinetorum; f- Palpada furcata.

flowers of many plant species visited by Syrphidae emit a perceptible odour. The fact that the flowers of B. alata emit a strong sweet odour could be an


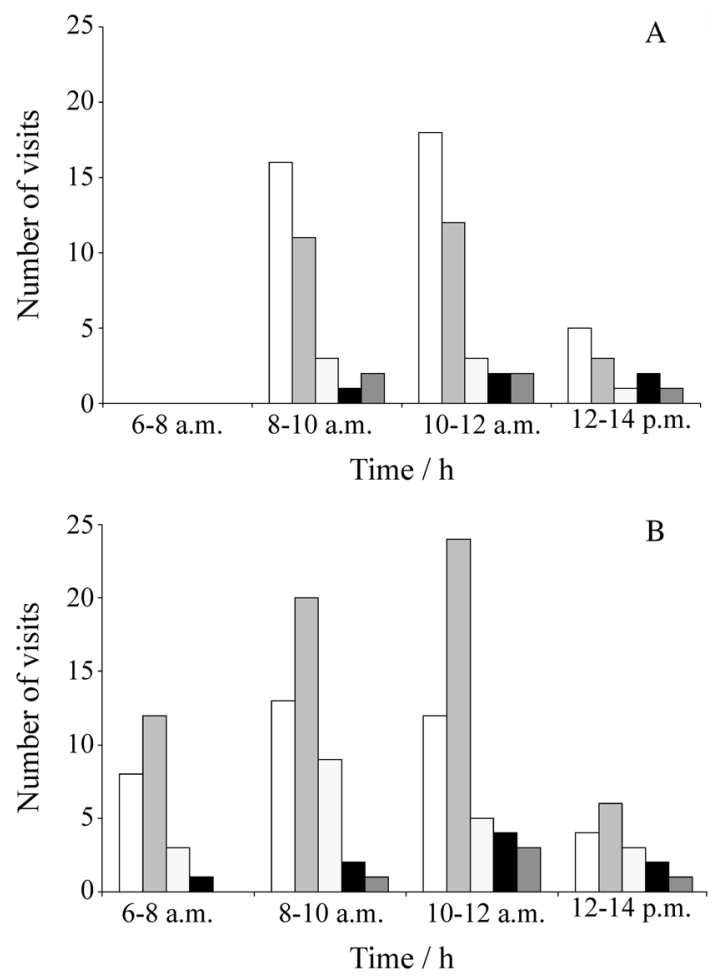

Figure 4. Average number of Dipteran visitors to flowers of Cordia multispicata (A) and Borreria alata (B) during three consecutive days.

advantage to that species in attracting flies over a long distance. However, this situation does not seem to occur, since the diversity and frequency of visitors to the flowers of $C$. multispicata and B. alata are similar, and they share seven species.

The frequency of flies visiting flowers of a species or an individual plant may be related to climate conditions (Arruda \& Sazima 1996, Vieira \& Silva 1997) and to the presence of other species of plants flowering at the same time (Arruda \& Sazima 1996). Under some conditions, co-occurring species may mutualistically favour or improve their reproduction (Brown \& Kodric-Brown 1979, Schemske 1981). Some studies, on the other hand, provide evidence that the convergence of floral characters in co-occurring species induces a competition for the same pollinators (Armbruster \& Herzig 1984, Yanagizawa \& Gottsberger 1982/83) and loss of pollen through interspecific pollen flow (Armbruster \& Herzig 1984). The floral similarity between $C$. multispicata and B. alata, the overlap in flowering time and the occupation of the same environment in the forest, in glades or edges, seem to be advantageous for both, resulting in benefits to them, since they may increase pollinator attraction. In a study carried out with $C$. multispicata in grazing areas in Amazon, Vieira \& Silva (1997) observed that, during the dry season, when the number of pollinators was low, the fruit set under natural conditions was also low, varying from 11 to $25 \%$, while in the rainy season it increased to 48 to $61 \%$. According to Vieira \& Silva (1997), the pollen flow between the two floral morphs of $C$. multispicata is small when the activity of the insects is reduced during the dry season, and it is one of the determinant factors of the low fruit set. Our data show that the fruit set of $48 \%$ under natural conditions in the forest of Dois Irmãos is very near to the maximum value obtained in the interform manual crossing (see table 1) in $C$. multispicata and indicates that activity and efficiency of pollinators are high in the study area.

Regarding the reproductive system, $C$. multispicata is self-incompatible and heterostylic with an isoplectic frequency of the two floral morphs, similar to many other distylic species of Boraginaceae or other families (Ornduff 1971, Sobrevila et al. 1983, Barrett \& Shore 1985, Richards \& Barrett 1992). The occurrence of heterostyly in Cordia is known since Darwin (1877) and it is considered the most common type of reproductive system in the genus (Opler et al. 1975). In $C$. multispicata the existing mutual correspondence related to the size of stamens and styles makes easier the intermorph pollen flow, similar to other species of Cordia (Opler et al. 1975).

Borreria alata, in turn, is probably a self-compatible species, with a high fruit set under natural conditions. The occurrence of apomixis was not tested. In the family Rubiaceae heterostyly also occurs widely. It was mentioned for 13 studied genera (Barrett \& Richards 1990), from the 91 heterostylous genera listed for this family (see Ganders 1979, Bir Bahadur 1968, Vuilleumier 1967). Barrett \& Richards (1990) did not include the genus Borreria in their list (even though it is mentioned in the lists of Bir Bahadur (1968) and Ganders (1979)) once the genus had not been effectively studied. The flowers of $B$. alata show a polymorphism related to the size of the style. Some species of Rubiaceae show a 
characteristic distyly, associated with a strong mechanism of self-incompatibility, as in Palicourea fendleri (Sobrevila et al. 1983). Other species show polymorphisms of the style that differ from those typically distylous, as occurred in Guettarda scabra (Richards \& Koptur 1993), a self-compatible species. It is possible that Borreria alata shows an "anomalous heteromorphism", as defined by Barret \& Richards (1990). Further studies would be interesting in order to analyse this hypothesis.

Acknowledgments - We thank Dr. A. X. Linhares for the identification of the flies and the researchers of the IPA Herbarium (Empresa Pernambucana de Pesquisa Agropecuária) for the identification of the plants. To Dr. S. Vogel, Msc. A. V. Lopes, Dr. C. Westerkamp and two anonymous reviewers for their critical comments and improving on the manuscript. The COMPESA for permission to work in lands under their care; the CNPq and CAPES for essential financial support.

\section{References}

ARMBRUSTER, W.S. \& HERZIG, A.L. 1984. Partitioning and sharing of pollinators by four sympatric species of Dalechampia (Euphorbiaceae) in Panama. Annals of the Missouri Botanical Garden 71:1-16.

ARRUDA V.L.V. \& SAZIMA, M. 1996. Flores visitadas por sirfídeos (Diptera: Syrphidae) em mata mesófila de Campinas, SP. Revista Brasileira de Botânica 19:109-117.

BAKER, H.G. 1975. Sugar concentrations in nectars from hummingbird flowers. Biotropica 7:37-41.

BARRETT, S.C.H. \& RICHARDS, J.H. 1990. Heterostyly in tropical plants. Memoirs of the New York Botanical Garden 55: 35-61.

BARRETT, S.C.H. \& SHORE, J.S. 1985. Dimorphic incompatibility in Turnera hermannioides Camb. (Turneraceae). Annals of the Missouri Botanical Garden 72:259-263.

BIR BAHADUR. 1968. Heterostyly in Rubiaceae. A review. Journal of the Osmania University. Golden Jubilee v.207-238

BROWN, J.H. \& KODRIC-BROWN, A. 1979. Convergence, competition, and mimicry in a temperate community of hummingbird-pollinated flowers. Ecology 60:1022-1035.

DARWIN, C. 1877. The different forms of flowers on plants of the same species. John Murray, London.

ENDRESS, P.K. 1994. Diversity and evolutionary biology of tropical flowers. Cambridge University Press, New York.
FAEGRI, K. \& VAN DER PIJL, L. 1979. The principles of pollination ecology. Pergamon Press, Oxford.

GANDERS, F.R. 1979. The biology of heterostyly. New Zealand Journal of Botany 17:607-635.

OPLER, P.A., BAKER, H.G. \& FRANKIE, G.W. 1975. Reproductive biology of some Costa Rican Cordia species (Boraginaceae). Biotropica 7:234-247.

ORNDUFF, O. 1971. The reproductive system of Jepsonia heterandra. Evolution 25:300-311.

PERCIVAL, M. 1965. Floral biology. Pergamon Press, London.

PERCIVAL, M. 1974. Floral ecology of coastal scrub in southeast Jamaica. Biotropica 6:104-129.

POMBAL, E.C.P. \& MORELLATO, L.P.C. 1995. Polinização por moscas em Dendropanax cuneatum Decne. \& Planch. (Araliaceae) em floresta semidecídua no sudeste do Brasil. Revista Brasileira de Botânica 18:157-162.

PROCTOR, M., YEO, P. \& LACK, A. 1996. The natural history of pollination. Harper Collins Publishers, London.

RADFORD, A.E., DICKINSON, W.C., MASSEY, J.R. \& BELL, C.R. 1974. Vascular plant systematics. Harper \& Row, New York.

RICHARDS, J.H. \& BARRETT, S.C.H. 1992. The development of heterostyly. In Evolution and function of heterostyly. (S.C.H. Barrett, ed.) Springer-Verlag, New York, p.85-127.

RICHARDS, J.H. \& KOPTUR, S. 1993. Floral variation and distyly in Guettarda scabra (Rubiaceae). American Journal of Botany 80:31-40.

SCHEMSKE, D.W. 1981. Floral convergence and pollinator sharing in two bee-pollinated tropical herbs. Ecology 62:946-954.

SOBREVILA, C., RAMIREZ, N. \& DE ENRECH, N.X. 1983. Reproductive biology of Palicourea fendleri and $P$. petiolaris (Rubiaceae), heterostylous shrubs of a tropical cloud forest in Venezuela. Biotropica 15:161-169.

VIEIRA, I.C.G. \& SILVA, J.M.C. 1997. Phenology, fruit set and dispersal of Cordia multispicata Cham., an important weed shrub of abandoned pastures in eastern Amazonia. Revista Brasileira de Botânica 20:51-56.

VOGEL, S. 1983. Ecophysiology of zoophilic pollination. In Physiology plant ecology III. (O.L. Lange, P.S. Nobel, C.B. Osmond \& H. Ziegler, eds.). Springer-Verlag, Berlin, p.560-624.

VUILLEUMIER, B. 1967. The origin and evolutionary development of heterostyly in the angiosperms. Evolution 21:210-226.

WEEMS, H.V. 1953. Notes on collecting syrphid flies (Diptera: Syrphidae). Florida Entomologist 36:91-98.

YANAGIZAWA, Y. \& GOTTSBERGER, G. 1982/1983. Competição entre Distictella elongata (Bignoniaceae) e Crotalaria anagyroides (Fabaceae) com relação as abelhas polinizadoras no cerrado de Botucatu, Estado de São Paulo, Brasil. Portugaliae Acta Biologica 17:149-166. 